\title{
Optimalisasi Bantuan Luar Negeri untuk Rehabilitasi Bencana Alam melalui Pemberdayaan Microfinance
}

\author{
Rokhedi P. Santoso
}

The following article investigates the disaster constitutes not only humanity problem but also that of development. The impact of disaster generally more crucial toward poor people, so disaster denotes one of many factors that implies increasing poverty. International aid for emergency, rehabilitation or reconstruction should need management in order to minimize the impact of disaster, for instance microfinance. Microfinance has proved successful to decrease impact of disaster risks, to prevent, to recovery economic life after happening disaster.

Kata kunci: bencana, rehabilitasi, menejemen, microfinance

Setiap bencana alam selalu meninggalkan
kemanusiaan. Apalagi bila bencana alam
tersebut sifatnya sangat dahsyat dan
menimbulkan kerusakan fisik yang sangat
parah dan menyebabkan korban jiwa yang
tidak sedikit. Bencana alam yang terjadi di
negara-negara kawasan Samudera Hindia
pada akhir tahun 2004 berupa gempa bumi
yang diikuti gelombang tsunami bukan
merupakan bencana alam biasa. Bencana
alam tersebut telah meninggalkan
permasalahan kemanusiaan yang sangat
mendalam yang merupakan pekerjaan dan
tantangan bagi Indonesia maupun
masyarakat internasional.

Oleh karena permasalahan kemanusiaan adalah bersifat universal, setiap bencana alam selalu mampu menggugah hati nurani setiap insan manusia di mana pun berada untuk selalu ingin meringankan beban penderitaan korban bencana alam. Di samping itu, penangangan dampak bencana yang sangat luar biasa seperti terjadi di Nangroe Aceh Darussalam (NAD) tidak mampu apabila dibebankan hanya pada satu negara tertentu saja. Tidak mengherankan kemudian apabila bantuan (assistance) baik yang bersifat financial maupun technical assistance dalam jumlah yang sangat besar mengalir dari dalam maupun luar negeri untuk membantu para korban.

\section{Mensikapi Bantuan Internasional Bagi Penanggulangan Bencana Alam}

Dalam kasus bencana alam tsunami yang melanda Kawasan Asia terdapat komitmen bantuan masyarakat internasional yang tertuang dalam Deklarasi tentang Aksi untuk Memperkuat Bantuan Darurat, Rehabilitasi, Rekonstruksi dan Pencegahan Atas Dampak Bencana Gempa Bumi dan Tsunami. Komitmen tersebut berasal dari 
berbagai negara, organisasi internasional dan organisasi regional. Bentuk komitmen tersebut antara lain berupa penggalangan dana bagi upaya darurat, rehabilitasi dan rekonstruksi; moratorium pembayaran hutang luar negerinya dalam rangka meningkatkan kapasitas negara tersebut untuk melakukan rehabilitasi maupun rekonstruksi; serta bentuk-bentuk pencegahan dan mitigasi bencana alam. Secara khusus bentuk bantuan financial yang diberikan berupa grant maupun con-sessional fund yang jumlahnya untuk Indonesia senilai US $\$ 4$ milliar. Sebuah angka yang sangat besar sekali.

Besarnya bantuan yang sebagian berwujud pinjaman bagi Indonesia telah menimbulkan reaksi menentang dari masyarakat domestik. Penilaian mereka adalah bantuan yang diberikan tersebut bukan tanpa 'biaya' baik biaya ekonomi maupun biaya sosial. Bantuan maupun penundaan pembayaran hutang luar negeri tersebut membawa konsekuensi membebani anggaran di masa yang akan datang; maupun bantuan tersebut juga mensyaratkan biaya kompensasi dan supervisi yang tidak sedikit agar sampai pada kelompok masyarakat yang dibantu. Lembaga pemberi donor yang biasa berperan dalam memberikan bantuan juga bukan mumi sebagai lembaga non profit akan tetapi juga beroperasi secara komersial seperti Bank Dunia, Bank Pembangunan Asia maupun International Monetary Fund (IMP).

Sebagian kalangan juga menggunakan alasan harga diri Indonesia sebagai negara pengutang yang akan semakin terpuruk. Lebih mendasar daripada itu mereka menilai pemerintah tidak memiliki kemampuan untuk menyelesaikan permasalahan secara lebih terhormat di mata masyarakat domestikmaupun intemasional. Masyarakat telah banyak belajar dari bantuan IMF dalam mengatasi krisis ekonomi di Indonesia yang justru terjerumus paling parah di antara negara ASEAN lainnya. Malaysia yang telah mendeklarasikan tidak mengadopsi :IMF justru telah dengan cepat keluar dari krisis dan telah mencapai kemajuan yang luar biasa secara negara yang telah pulih dari krisis. Sedangkan dalam konteks bantuan bencana alam, India merupakan negara yang secara tegas menolak untuk menambah dan terlibat dalam bantuan yang ditawarkan dan mereka teiah bertekad untuk menyelesaikan permasalahan dampak bencana alam dengan menggunakan sumberdaya yang mereka miliki saat ini. Pengalaman pahit negara Iran dimana realisasi bantuan luar negeri untuk rehabilitasi korban gempa bumi yang sangat jauh dari nilai komitmennya. Kejadian seperti ini dikhawatirkan menyebabkan kekecewaan masyarakat domestik. Pengalaman empiric tersebut merupakan beberapa pelajaran dari negeri tetangga yang telah mendidik cara berfikir masyarakat Indonesia lebih dewasa dalam menilai kebijakan pemerintah yang sensitif misalnya dalam mengadopsi bantuan luar negeri.

Tujuan utama pemerintah Indonesia dalam mengadopsi bantuan adalah meringankan beban pemerintah dalam merehabilitasi dan merekonstruksi masyarakat agar cepat pulih dari kondisi bencana alam. Tujuan ini harus menjadi motivasi dan spirit utama untuk pengelolaan dana bantuan yang ada. Pemerintah harus tetap menyadari bahwa bantuan tersebut bukan tanpa biaya. Sebagian besar dana bantuan yang bersifat trust fund telah mensyaratkan adanya transparansi dan efektifitas alokasi dana supaya komitmen dana berikutnya bisa cair. Sehingga aliran dana bantuan internasional yang sangat besar menuntut suatu sistem pengelolaan bantuan sécara tepat dan optimal. 
Bantuan internasional bagi bencana alam di NAD akan menguji kredibilitas dan kesiapan Pemerintah Indonesia apakah mampu mengelola dan mengoptimalkan bantuan tersebut sehingga dapat meyakinkan masyarakat internasional terutama pihak pemberi donor baik pemerintah negara lain, lembaga internasional maupun masyarakat umum. Sampai saat ini, pemerintah Indonesia belum memiliki konsep yang jelas dalam pengelolaan dana bantuan internasional dalam rangka rehabilitasi dan rekonstruksi masyarakat pasca bencana. Pola pengelolaan bantuan yang baik diharapkan dapat menjadi pelajaran berharga bagi pemerintah dalam rangka mensikapi, menghadapi dan mengelola bencana alam di Indonesia yang sangat mungkin sekali bencana tsunami NAD dan Sumatera Utara hanya merupakan contoh kecil dari bencana-bencana yang akan terjadi.

\section{Optimalisasi Pemanfaatan Bantuan: Microfinance untuk Mengurangi Kemiskinạn}

Bencana alam bukan hanya merupakan masalah kemanusiaan saja akan tetapi juga merupakan permasalahan pembangunan. Tingkat kematian yang disebabkan oleh bencana alam besarnya 4 kali lipat pada kelompok masyarakat miskin. Bencanaalam juga merupe kan penyebab hilangnya hasil-hasil pembangunan dan kesejahteraan di negara berkembang. GDP hilang sampai dengan $2 \%-15 \%$. Menurut penilaian yang dilakukan oleh beberapa lembaga internasional dan Pemerintah Indonesia, secara finansial total kerugian di NAD sebesar US $\$ 4.45$ milliar setara dengan $97 \%$ GDP NAD. Sedangkan di India sebesar US $\$$ 575 juta. Menurut Bank Dunia, kerugian per tahun akibat bencana alam selama tahun 1990 -an sebesar US $\$ 63$ milliar. Sedangkan kerusakan infrastruktur selama tahun 1990 . an di Asia sendiri sebesar US\$120 miliar atau sekitar $2 / 3$ total pinjaman tahunan Bank Dunia. Bank dunia menilai bahwa bencana alam sebagai "unrecognized sector" dimana selama tahun 1980-2003 total pinjaman yang diberikan dalam rangka bencana alam sebesar lebih dari US $\$ 40$ milliar. Oleh karena dampak bencana alam terutama dirasakan oleh kelompok masyarakat miskin sehingga bencana tersebut sangat berpotensi untuk meningkatkan kemiskinan. Oleh karena kemiskinan merupakan permasalahan yang lebih kompleks maka diperlukan pendekatan pembangunan yang tepat dan aktif daiam rangka mengurangi resiko dampak bencana alam tersebut.

Dalam rangka optimalisasi pengelolaan bantuan, pengalaman penerapan sistem microfinance untuk merehabilitasi dan merekonstruksi masyarakat pasca bencana alam menunjukkan tingkat kesuksesan dan keberhasilan di banyak wilayah terutama dalam menguangi tingkat kemiskinan. Artikel ini akan menganalisis bagaimana optimalitas pengelolaan dana bantuan internasional melalui pembiayaan dan pemberdayaan peran microfinance dapat mempercepat upaya rehabilitasi dan rekonstruksi masyarakat pasca bencana alam.

Efektivitas dan optimalisasi pengelolaan dana bantuan bencana alam mensyaratkan adanya perencanaan mikro (micro planning) yang menggunakan pendekatan partisipasi intensif dari masyarakat korban dalam merespon bencana alam itu sendirj (intensive community participation). Dengan konsep ini diharapkan penilaian (assessment) terhadap kerusakan - merupakan syarat yang harus ada sebelum turunnya dana - yang lebih akurat, dan mengurangi resiko bantuan yang salah sasaran, keteriambatan maupun melebarnya aliran 
bantuan. Belajar dari salah satu desa nelayan yang terkena bencana tsunami di India, kurang dari satu bulan setelah bencana mereka telah memiliki sebuah microplanning untuk merekonstruksi wilayah mereka, dimana private bank telah mampu menyediakan kredit pinjaman, dana investasi dari masyarakat (community investment fund) juga telah tersedia serta masyarakat telah mampu membeli kapal nelayan untuk pertama kali. Program yang mereka laksanakan adalah program-program yang dikembangkan oleh masyarakat itu sendiri (community-driven development program).

Selaras dengan konsep communitydriven development program, pemerintah perlu mengalokasikan sebagian besar dana bantuan - setelah digunakan untuk kepentingan darurat (emergency relief)untuk aktifitas rekonstruksi dan rehabilitasi yang lebih efektif dan mendorong investasi yang berkesinambungan dengan mengembangkan dan memberdayakan lembaga-lembaga microfinance. Pengalaman daerah-daerah pasca bencana menunjukkan bahwa mereka bisa'pulih lebih cepat dengan membentuk dan memberdayakan microfinance.

Asian Development Bank melaporkan bahwa microfinance juga telah terbukti berhasil dalam mengurangi kemiskinan masyarakat Asia maupun Pasific. Contoh klasik keberhasilan microfinance adalah yang dilakukan oleh Grameen Bank di Bangladesh. Mereka mendukung pengembangan kelompok masyarakat rawan bencana alam selama periode bencana banjir 1988 - 1998 dengan menyediakan berbagai mekanisme bagi masyarakat untuk mendiversifikasi pendapatannya antar berbagai musim. Melaiui mekanisme yang disediakan bank ini, maka dampak bencana alam yang ditimbulkan kondisinya tidak separah dibandingkan tanpa microfinance.
Secara umum, pengertian microfinance sebenarnya merupakan mekanisme penyediaan pelayanan dana dalam cakupan yang luas seperti deposito, pinjaman, layanan pembayaran, transfer maupun asuransi bagi kelompok masyarakat miskin. Sumber bagi pembiayaan microfinance ini capat berbentuk lembaga formal seperti koperasi dan lembaga keuangan pedesaan, lembaga semiformal yaitu non government organization dan juga Iembaga informal. Namun demikian, peran microfinance temyata lebih flexible dalam kondisi bencana alam maupun pasca bencana alam. Mereka bisa dan biasa bertindak sebagai emergency relief di samping tentu saja prioritas utamanya adalah sebagai lembaga jasa keuangan pada kondisi pemulihan pasca bencana.

Lembaga keuangan mikro tersebut mampu membantu masyarakat dalam mengelola resiko bencana alam secara lebih baik. Pengalaman selama ini menunjukkan kelebihan lembaga microfinance dalam melayani kelompok masyarakat miskin dan rentan secara lebih menguntungkan, yang akhirnya dapat merangkul masyarakat atau klien yang lebih banyak. Dengan tantangan yang dihadapi oleh lembaga ini berupa pengembangan kapasitas kelembagaan, pengembangan produk-produkyang responsive, dan pengembangan model bisnis yang menjamin kesinambungan, maka tantangan microfinance akan lebih berat pada kondisi dimana terjadi bencana alam. Tantangan tersebut terkait dengan sifat bencana alam telah meningkatkan berbagai kerentanan masyarakat miskin karena mereka kehilangan property, memburuknya kesehatan dan mereka hidup dalam kondisi yang memprihatinkan. Penelitian menunjukkan bahwa ketika terjadi bencana alam, kelompok miskin tidak hanya menjadi korban akan tetapi juga mengalami kerugian 
yang lebih besar dibandingkan kolompok masyarakat lainnya. Dengan demikian, lembaga microfinance yang berada di daerah bencana, mereka bekerja dengan resiko tinggi antara lain menghadapi penurunan kapasitas pembayaran pinjaman masyarakat, dan resiko portofolio maupun likuiditas lainnya.

Fakta empirik lainnya menunjukkan bahwa tersedianya akses masyarakat kepada pelayanan microfinance dapat mendukung kesiapan masyarakat dalam menghadapi bencana dan mampu mengurangi berbagai kerentanan akibat bencana alam. Ketika masyarakat mempunyai akses pelayanan keuangan selama bencana, maka dampak bencana mungkin dapat diturunkan. Penyediaan pelayanan finansial selama bencana hanya dapat dilakukan apabila lembaga microfinance disiapkan untuk itu. Ketidaksiapan lembaga hanya akan menambah resiko kerentanan. Untuk itulah peran pemerintah diharapkan lebih aktif dalam mengembangkan dan membina lembaga-lembaga microfinance agar lebih mapan sehingga lebih siap masih dapat berperan optimal dalam menghadapi kondisi terburuk seperti bencana alam.

Di samping kelebihan lembaga microfinance sebagai penyedia berbagai layanan jasa keuangan, dalam situasi bencana alam dan merehabilitasi kondisi masyarakat pasca bencana alam, lembaga microfinance memungkinkan untuk menjalankan berbagai peran antara lain relief efforts saat emergency, mengelola tabungan masyarakat sampai kondisi pulih kembali, melakukan skema kebijakan loan rescheduling atau penjadwalan kembali pinjaman berupa pengunduran pembayaran maupun penangguhan pembayaran pokok dan bunga pinjaman, dan memberikan reconstruction loans pada masa pemulihan sepertj untuk pembangunan pemukiman maupun fasilitasnya. Aktivitas-aktivitas ini merupakan common practices yang dilakukan oleh lembaga microfinance pada kondisi bencana alam.

Bagaimana upaya yang dilakukan agar microfinance tetap exist pada kondisi bencana alam? Paparan di bawah ini adalah prinsip-prinsip yang harus dipegang agar mereka dapat berkembang dan berperan secara optimal dalam memulihkan kondisi bencana alam. Pertama, meskipun dalam masa emergency microfinance dapat berperan sebagai lembaga yang menspesialisasikan untuk emergency relief akan tetapi segera masa pasca bencana, microfinance harus segera beroperasi secara normal kembali sebagai lembaga penyedia jasa keuangan. Karena memang hakekat lembaga ini adalah sebagai penyedia jasa keuangan. Setiap micro-finance harus tetap menjaga komitmen agar tetap dapat beroperasi secara berkesinambungan dalam jangka panjang. Hal ini merupakan prinsip penting agar micro-finance tetap dapat berkembang. Kedua, dalam kondisi bencana alam, tidak semua orang mengalami keberuntungan yang sama. Sehingga microfinance harus dapat menyesuaikan bentuk pelayanan sesuai dengan kondisi masyarakat yang dilayani. Agar dapat menyesuaikan tuntutan tersebut, maka sumberdaya manusianya harus mampu menilai situasi dan mengambil keputusan dengan cepat. Pola seperti ini lebih efisien daripada kebijakan yang sifatnya sama untukseluruh masyarakat dan memungkinkan pelaksana untuk selalu melakukan kontak setelah masa pemulihan. Ketiga, dalam menja-iankan perannya, microfinance harus tetap realistis mengenai batas peran dan kemampuan mereka. Semakin kecil suatu microfinance maka kemampuan mereka dalam masalah likuiditas, sumberdaya, fleksibilitas untuk 
menjalankan peran juga terbatas. Untuk itu partnership dengan bank komersial atau microfinance lainnya diperlukan.

\section{Penutup}

Pengelolaan dana bantuan intemasional yang sangat besar memerlukan suatu sistem dan mekanisme yang komplek dan mapan. Dilihat dari kecenderungan dan pengalaman empirik penanganan masalah bencana alam di Indonesia, pemerintah dipandang tidakcukup memiliki kemampuan untukmelaksanakan penangangan tersebut secara sendirian sehingga peran lembaga non pemerintah tampak lebih menonjol. Dalam rangka mengantisipasi kejadian bencana alam lainnya, untuk itu pemerintah perlu mempersiapkan masyarakat yang nantinya dapat menjadi mitra pemerintah dalam menjalankan perannya. Kebijakan pemerintah dalam mengembangan lembagalembaga microfinance merupakan upaya dalam rangka menyiapkan kondisi sosial ekonomi masyarakat agar lebih siap dalam menghadapi dampak dan resiko suatu bencana alam. Dalam masa pemulihan bencana alam, lembaga ini juga perlu diberikan peran yang lebih luas dalam menyediakan berbagai mekanisme pelayanan pengembangan ekonomi suatu komunitas rawan bencana alam. Dengan demikian alokasi pemanfaatan dana bantuan bisa tercapai secara optimal dan efektif serta sesuai sasaran. Hal ini karena karakteristik dari lembaga microfinance merupakan lembaga yang dikembangkan dan bergerak berdasarkan karakter sosio-ekonomi masyarakat sehingga dapat dapat berperan efektif dalam menyelesaikan permasalahan riil yang dihadapi oleh masyarakat rawan bencana alam.

\section{Daftar Pustaka}

Eileen Miamidian, Margaret Arnold, Kiendel Burritt, Marc Jacquand, Surviving Disasters and Supporting Recovery: A Guidebook for Microfinance Institutions, working paper series No. 10 , Hazard Management Unit, World Bank

Geetha Nagarajan, Microfinance in the Wake of Natural Disasters: Challenges and Opportunities, $D A I-D e$ velopment Altematives, Inc. - June 1998

Margaret Arnold, Financing Disaster Risk: The Role of the World Bank, WCDR, Kobe, Hyogo, Japan, 2005

Microenterprise Best Practices Project, Loan Rescheduling After a Natural Disaster, USAID, 1998

Stuart Mathison, Microfinance and Disaster Management, The Foundation for Development Cooperation, 2003

The ASEAN Leaders' Special Summit Earthquake and Tsunami Disaster, Briefing Paper, Jakarta, 2005

www.worldbank.org

www.adb.org

www.un.org 